\title{
Lactotransferrin gene functional polymorphisms do not influence susceptibility to human immunodeficiency virus-1 mother-to-child transmission in different ethnic groups
}

\author{
Luisa Zupin'1, Vania Polesello', Antonio Victor Campos Coelho², Michele Boniotto ${ }^{3}$, \\ Luiz Claudio Arraes ${ }^{4}$, Ludovica Segat ${ }^{1 /+}$, Sergio Crovella ${ }^{1,5}$ \\ ${ }^{1}$ Institute for Maternal and Child Health, Scientific Institute For Research, Hospitalization and Care Burlo Garofolo, Trieste, Italy \\ ${ }^{2}$ Departamento de Genética, Universidade Federal de Pernambuco, Recife, PE, Brasil ${ }^{3}$ Faculty of Medicine, National Institute of Health and \\ Medical Research, University of Paris-Est Créteil, Créteil, France ${ }^{4}$ Instituto de Medicina Integrada Prof Fernando Figueira, Recife, PE, Brasil \\ ${ }^{5}$ Department of Medicine, Surgery and Health Sciences, University of Trieste, Trieste, Italy
}

Lactotransferrin, also known as lactoferrin, is an iron binding glycoprotein that displays antiviral activity against many different infectious agents, including human immunodeficiency virus (HIV)-1. Lactotransferrin is present in the breast milk and in the female genitourinary mucosa and it has been hypothesised as a possible candidate to prevent mother-to-child HIV-1 transmission. To verify if two functional polymorphisms, Thr29Ala and Arg47Lys, in the lactotransferrin encoding gene (LTF) could affect HIV-1 infection and vertical transmission, a preliminary association study was performed in 238 HIV-1 positive and 99 HIV-1 negative children from Brazil, Italy, Africa and India. No statistically significant association for the Thr29Ala and Arg47Lys LTF polymorphisms and HIV-1 susceptibility in the studied populations was found. Additionally LTF polymorphisms frequencies were compared between the four different ethnic groups.

Key words: AIDS - HIV-1 - innate immunity - lactoferrin - SNPs - vertical transmission

In 2013, about 240,000 children acquired human immunodeficiency virus (HIV)-1 infection worldwide (WHO 2013). The main route of HIV-1 infection for a child is through the HIV-1 positive mother, during delivery or breastfeeding. Without antiretroviral intervention, caesarean delivery (Legardy-Williams et al. 2010) or safer alternatives to breastfeeding, the transmission rate of HIV-1 from an infected mother to her infant varies from $30-45 \%$ (Datta et al. 1994).

In this context, innate immunity effector molecules have an important role in fighting against HIV-1 infection. Among them, lactotransferrin (also known as lactoferrin) seemed to be a possible candidate to prevent mother-to-child transmission (MTCT) of the virus. Lactotransferrin, in fact, has been reported as possessing antiviral activity against HIV-1: through the binding to dendritic cell-specific intercellular adhesion molecule3 -grabbing non-integrin, the protein blocks the attachment to the viral gp120, so the virus transmission from dendritic cells to T cells is inhibited (Groot et al. 2005).

Lactotransferrin is found in breast milk and at the mucosal level in the female genitourinary tract (Kazmi et al. 2006): a reduction in maternal serum lactotransferrin has

doi: 10.1590/0074-02760140447

Financial support: Italian Ministry of Health (RC 2007) (FVG 2006) LZ and VP have fellowships from IRCCS Burlo Garofolo.

+ Corresponding author: ludovica.segat@burlo.trieste.it

Received 26 November 2014

Accepted 5 March 2015 been correlated with increased risk of HIV-1 MTCT (Defer et al. 1995, Semba et al. 1998). Reduced lactotransferrin serum level have been detected in HIV-1 infected individuals compared to healthy controls (Dapsanse et al. 2001) and in acquired immune deficiency syndrome (AIDS) patients compared to asymptomatic and symptomatic HIV-1 positive individuals or controls (van der Strate et al. 2001).

The LTF gene (chromosomal localisation: 3p21.3) encodes lactotransferrin; more than 60 single nucleotide polymorphisms (SNPs) have been identified within the promoter region, exons or introns. Two nonsynonymous polymorphisms, Thr29Ala and Arg47Lys (rs1126477 and rs1126478, respectively) in the first exon of the $L T F$ gene, resulting in amino acid changes in the mature peptide and located within the strongly basic $\mathrm{N}$-terminal region of the protein, that mediates its antibacterial properties (Shanbacher et al. 1992) have been described as associated with different pathologies, such as periodontitis (Velliyagounder et al. 2003, Jordan et al. 2005, Wu et al. 2009), dental caries (Azevedo et al. 2010, Fine et al. 2013), ovarian cancer (Cao et al. 2011), nasopharyngeal carcinoma (Zhou et al. 2012), dyslipidaemia (Moreno-Navarrete et al. 2008) and coronary artery stenosis (Videm et al. 2012).

The Thr29Ala amino acid change results from an A-G substitution at nucleotide 88 and the Arg47Lys change results from an A-G transition at nucleotide 140 (Teng \& Gladwell 2006).

This preliminary study aims at investigating the role of these two nonsynonymous SNPs in HIV-1 positive newborns infected by vertical transmission and children not infected but born from HIV-1 positive mothers, in four different populations from Brazil, Italy, Africa and India. Frequency differences within the four ethnic groups will be also described. 


\section{SUBJECTS, MATERIALS AND METHODS}

Patients - Genomic DNAs from 238 HIV-1 positive children (all within 6 and 14 years of age; 126 females - 53\% and 112 males - 47\%) were obtained. The sample consisted of 78 Brazilian children ( 40 females and 38 males) from the state of Pernambuco, Northeast Region of Brazil, collected at the Prof Fernando Figueira Integral Medicine Institute, Recife, 89 Italians (49 females and 40 males), collected at the Children Hospital Regina Margherita, Turin, 26 Zimbabwe Africans (14 females and 12 males) and 45 Kerala Indians (23 females and 22 males). The last two samples both came from a historical cohort kindly provided by Prof Trabattoni (Sacco Hospital, Milan, Italy).

The children were infected during delivery [exposed infected (EI)]. Ninety-nine exposed uninfected (EU) HIV-1 negative children (all within 6 and 14 years of age; 53 females - 54\% and 46 males - 46\%; 35 Brazilian, 20 females and 15 males; 18 Italian, 9 females and 9 males; 15 Zimbabwe African, 9 females and 6 males; 31 Kerala Indians, 15 females and 16 males), born from HIV-1 positive mothers, were already available at the Laboratory of Immunogenetics of Scientific Institute For Research, Hospitalization and Care (IRCCS) Burlo Garofolo and were used for this study. Biological material from the mothers was not available and the sole information available to us was that none of the infected mothers underwent antiretroviral therapy before delivery or caesarean section to prevent HIV-1 infection of the newborns.

DNA extraction and SNPS genotyping - DNA extraction from whole blood was performed using the DNeasy Blood and Tissue Kit (Qiagen, Germany), in accordance with the manufacturers' manual.

The two LTF (National Center for Biotechnology Information Reference Sequence: NC 000003), functional SNPs, Thr29Ala and Arg47Lys (rs1126477 and rs1126478, respectively) were genotyped by real time polymerase chain reaction (PCR) using C__ 9698511 10 and C__9698521_10 fluorogenic allele-specific TaqMan SNPs genotyping assay probes (Applied Biosystems-Life Technologies, USA) on the ABI7900HT Real Time PCR platform (Applied Biosystems), following manufacturer instructions: an initial step for Taq polymerase activation at $95^{\circ} \mathrm{C}$ for $10 \mathrm{~min}$ followed by 40 cycles with $15 \mathrm{~s}$ of $95^{\circ} \mathrm{C}$ for denaturation and $1 \mathrm{~min}$ at $60^{\circ} \mathrm{C}$ for extension.

Allelic discrimination was done both manually and automatically with the SDS detection software (Applied Biosystems).

Real time allele specific PCRs results were double checked by direct sequencing performed on 50 randomly chosen samples and $100 \%$ of concordance was found.

Statistical analysis - LTF gene polymorphisms, allele and genotype frequencies were calculated by direct counting, while haplotype frequencies were computed using the Arlequin software v.3.1 (Excoffier \& Lischer 2010).

The Fisher's exact test for pairwise comparison of allele, genotype and haplotype frequencies (using contingency tables as appropriate) was performed with the open-source R v.3.1.0 (R Development Core Team 2014). Only p values $<0.01$ were considered to be significant. $\mathrm{p}$ values for linkage disequilibrium (LD) analysis were calculated using the permutation test with the EM algorithm, Arlequin software (Excoffier \& Lischer 2010), whereas D, D' and $\mathrm{r}^{2}$ measures were computed with SNPstat (Sole et al. 2006, Clayton 2013). Post-hoc power calculations were performed through G*Power software v.3.1.9.2 (Faul et al. 2007).

Ethics - Two independent ethical committees, one from IRCCS Burlo Garofolo (protocol L-1106, 1 May 2010), the other from Prof Fernando Figueira Integral Medicine Institute (registration 2273-11), responsible for all patients' biological samples (from 4 populations), approved the retrospective study.

All study experiments and procedures have been performed in accordance with the ethical standards of the Declaration of Helsinki.

\section{RESULTS}

The genotype frequencies of Thr29Ala and Arg47Lys polymorphisms of the $L T F$ gene were assessed in 238 HIV-1 positive children (EI) and 99 HIV-1 negative (EU) children all born from HIV-1 positive women from four different populations. The polymorphisms were in Hardy-Weinberg equilibrium in all groups, except for the Thr29Ala in the EU Indians group and Arg47Lys in the EI African group (Tables I, II).

The Thr29Ala A allele was the major allele in the African population ( $76 \%$ in the $\mathrm{EU}$ and $77 \%$ in the $\mathrm{EI})$ and in the Brazilian one (51\% in the EU and $52 \%$ in the EI), whereas in Indians and Italians, the A allele was the minor one $(47 \%$ in EU and $39 \%$ in the EI in Indians and $25 \%$ in EU and 21\% in EI in Italians, respectively) (Table I).

The Arg47Lys A allele was the major allele in the Italian population $(64 \%$ in the EU and $60 \%$ in the EI), while it was the minor allele in the African population (3\% in the EU and $4 \%$ in the EI), among Indians (34\% in the $\mathrm{EU}$ and $36 \%$ in the $\mathrm{EI}$ ) and Brazilian individuals ( $43 \%$ in the EU and $33 \%$ in the EI) (Table II).

The frequency data of each population were compared using Fisher's exact test with the most similar ethnic group reported by the HapMap project (International HapMap Consortium 2003) and 1000 Genomes project (GPC et al. 2012). The Italian population was compared with the HapMap-TSI population, Tuscans in Italy; the African population with the Sub-Saharan Africa HapMap-YRI population, Yoruba in Ibadan, Nigeria; the Brazilian population with 1000 Genomes-AMR population, an admixture of Colombian from Medellin, Colombia, Mexican ancestry from Los Angeles, United States of America, Puerto Ricans from Puerto Rica; the Indian population with 1000 Genomes-ASN population, an admixture from Han-Chinese in Beijng, China, Southern Han Chinese, Japanese in Tokyo, Japan.

The Thr29Ala and Arg47Lys frequencies were simi$\operatorname{lar}(\mathrm{p}>0.05)$ for the populations from Africa, Italy and India. Comparing the Brazilian population of our study with an admixed population from 1000 Genomes, AMR population (to serve as a proxy to the admixed Brazilian populations), the Thr29Ala A allele was more frequent in the Brazilian sample (52\%) respect to AMR (41\%). 
TABLE I

LTF Thr29Ala polymorphism allele, genotype frequencies (and counts) in human immunodeficiency virus (HIV) positive (+) and negative (-) children in the four different populations analysed

\begin{tabular}{|c|c|c|c|}
\hline $\begin{array}{l}\text { LTF SNP } \\
\text { Thr29Ala (rs1126477) }\end{array}$ & HIV- & HIV+ & $\begin{array}{l}\text { HIV-vs. HIV+ } \\
\text { p (CI) OR }\end{array}$ \\
\hline Africa & $\mathrm{n}=15$ & $\mathrm{n}=26$ & \\
\hline A & $0.76(23)$ & $0.77(40)$ & Reference \\
\hline $\mathrm{G}$ & $0.23(7)$ & $0.23(12)$ & $1.00(0.30-3.40) 0.99$ \\
\hline $\mathrm{A} / \mathrm{A}$ & $0.60(9)$ & $0.61(16)$ & Reference \\
\hline $\mathrm{A} / \mathrm{G}$ & $0.33(5)$ & $0.31(8)$ & $1.00(0.19-4.64) 0.90$ \\
\hline $\mathrm{G} / \mathrm{G}$ & $0.07(1)$ & $0.08(2)$ & $1.00(0.05-73.62) 1.12$ \\
\hline $\operatorname{HWE}\left(\chi^{2} ; p\right)$ & $0.07 ; 0.79$ & $0.46 ; 0.50$ & - \\
\hline India & $\mathrm{n}=31$ & $\mathrm{n}=45$ & \\
\hline A & $0.47(29)$ & $0.39(35)$ & Reference \\
\hline $\mathrm{G}$ & $0.53(33)$ & $0.61(55)$ & $0.40(0.68-2.80) 1.38$ \\
\hline $\mathrm{A} / \mathrm{A}$ & $0.13(4)$ & $0.16(7)$ & Reference \\
\hline $\mathrm{A} / \mathrm{G}$ & $0.68(21)$ & $0.47(21)$ & $0.51(0.11-2.68) 0.58$ \\
\hline $\mathrm{G} / \mathrm{G}$ & $0.19(6)$ & $0.38(17)$ & $0.69(0.25-9.53) 1.59$ \\
\hline $\operatorname{HWE}\left(\chi^{2} ; p\right)$ & $4.03 ; 0.04$ & $0.01 ; 0.90$ & - \\
\hline Brazil & $\mathrm{n}=35$ & $\mathrm{n}=78$ & \\
\hline A & $0.51(36)$ & $0.52(81)$ & Reference \\
\hline $\mathrm{G}$ & $0.49(34)$ & $0.48(75)$ & $1.00 ;(0.54-1.79) 0.98$ \\
\hline $\mathrm{A} / \mathrm{A}$ & $0.31(11)$ & $0.32(25)$ & Reference \\
\hline $\mathrm{A} / \mathrm{G}$ & $0.40(14)$ & $0.40(31)$ & $1.00(0.34-2.78) 0.97$ \\
\hline $\mathrm{G} / \mathrm{G}$ & $0.29(10)$ & $0.28(22)$ & $1.00(0.31-3.09) 0.97$ \\
\hline $\operatorname{HWE}\left(\chi^{2} ; p\right)$ & $1.39 ; 0.24$ & $3.24 ; 0.07$ & - \\
\hline Italy & $\mathrm{n}=18$ & $\mathrm{n}=89$ & \\
\hline A & $0.25(9)$ & $0.31(55)$ & Reference \\
\hline G & $0.75(27)$ & $0.69(123)$ & $0.55(0.56-3.46) 1.34$ \\
\hline $\mathrm{A} / \mathrm{A}$ & $0.06(1)$ & $0.12(11)$ & Reference \\
\hline $\mathrm{A} / \mathrm{G}$ & $0.39(7)$ & $0.37(33)$ & $1.00 ;(0.32-3.61) 1.05$ \\
\hline $\mathrm{G} / \mathrm{G}$ & $0.56(10)$ & $0.51(45)$ & $0.67(0.28-115.53) 2.42$ \\
\hline $\operatorname{HWE}\left(\chi^{2} ; p\right)$ & $0.02 ; 0.87$ & $1.54 ; 0.21$ & - \\
\hline
\end{tabular}

CI: confidence interval; HWE: Hardy Weinberg equilibrium; LTF: lactoferrin encoding gene; OR: odds ratio; SNP: single nucleotide polymorphism.

The Arg47Lys G allele was more represented among our Brazilian population than AMR population $(57 \%$ and $47 \%$ respectively). Moreover the $\mathrm{G} / \mathrm{G}$ genotype was more frequent in our Brazilian population, whereas A/G and $\mathrm{A} / \mathrm{A}$ genotype were more frequent in the AMR population (Tables III, IV).

Therefore, the allele and genotype frequencies of both polymorphisms were not statistically different when comparing EI with EU children in our populations (Tables I, II).

The Thr29Ala and Arg47Lys polymorphisms were in LD ( $p<0.07$, D'statistic $>0.72 ; \mathrm{r}^{2}$ statistic $>0.11$ for all groups) and combined to form three major haplotypes $(\mathrm{AG}, \mathrm{GG}$ and $\mathrm{GA}$, with frequencies $>0.01)$ and one minor $(\mathrm{AA}$, with frequency $\leq 0.01)$. Comparing the haplotype frequencies between EU and EI in the four populations, no statistically significant differences were observed when using Fisher test with 4 x 2 table (Table V). The same results were obtained considering the most frequent haplotype as reference and analysing all other haplotypes vs. that reference (data not shown).

\section{DISCUSSION}

Several biological activities of lactotransferrin against HIV-1 have been described so far, ranging from the inhibition of virus-cell interaction through CXCR4 and CCR5 binding or viral gp120 V3 loop blocking (Berkhout et al. 2002), to inhibit viral processes within the host cells (Ng et al. 2001). Recently, Wong et al. (2014) have shown the inhibitory activity of lactotransferrin fragments lactoferricin and lactoferrampin against HIV-1 reverse transcriptase and integrase, respectively.

A reduction of the serum lactotransferrin concentration has previously been associated with increased HIV-1 
TABLE II

LTF Arg47Lys polymorphism allele, genotype frequencies (and counts) in human immunodeficiency virus (HIV) positive $(+)$ and negative $(-)$ children in the four different populations analysed

\begin{tabular}{|c|c|c|c|}
\hline $\begin{array}{l}L T F \text { SNP } \\
\text { Arg47Lys (rs1126478) }\end{array}$ & HIV- & HIV+ & $\begin{array}{l}\text { HIV- vs. HIV+ } \\
\text { p (CI) OR }\end{array}$ \\
\hline Africa & $\mathrm{n}=15$ & $\mathrm{n}=26$ & \\
\hline $\mathrm{G}$ & $0.97(29)$ & $0.96(50)$ & Reference \\
\hline A & $0.03(1)$ & $0.04(2)$ & $1.00(0.06-70.74) 1.16$ \\
\hline $\mathrm{G} / \mathrm{G}$ & $0.93(14)$ & $0.96(25)$ & Not calculable \\
\hline $\mathrm{A} / \mathrm{G}$ & $0.07(1)$ & $0.00(0)$ & Not calculable \\
\hline $\mathrm{A} / \mathrm{A}$ & $0.00(0)$ & $0.04(1)$ & Not calculable \\
\hline $\operatorname{HWE}\left(\chi^{2} ; p\right)$ & $0.02 ; 0.89$ & $26 ; 3.41 \mathrm{E}-07$ & \\
\hline India & $\mathrm{n}=31$ & $\mathrm{n}=45$ & - \\
\hline $\mathrm{G}$ & $0.66(41)$ & $0.64(58)$ & Reference \\
\hline A & $0.34(21)$ & $0.36(32)$ & $0.86(0.52-2.26) 1.08$ \\
\hline $\mathrm{G} / \mathrm{G}$ & $0.39(12)$ & $0.38(17)$ & Reference \\
\hline $\mathrm{A} / \mathrm{G}$ & $0.55(17)$ & $0.53(24)$ & $1.00(0.34-2.90) 0.99$ \\
\hline $\mathrm{A} / \mathrm{A}$ & $0.06(2)$ & $0.09(4)$ & $1.00(0.17-17.82) 1.40$ \\
\hline $\operatorname{HWE}\left(\chi^{2} ; p\right)$ & $1.56 ; 0.21$ & $1.21 ; 0.27$ & - \\
\hline Brazil & $\mathrm{n}=35$ & $\mathrm{n}=78$ & \\
\hline $\mathrm{G}$ & $0.57(40)$ & $0.67(104)$ & Reference \\
\hline A & $0.43(30)$ & $0.33(52)$ & $0.18(0.36-1.24) 0.67$ \\
\hline $\mathrm{G} / \mathrm{G}$ & $0.40(14)$ & $0.49(38)$ & Reference \\
\hline $\mathrm{A} / \mathrm{G}$ & $0.34(12)$ & $0.36(28)$ & $0.82(0.31-2.38) 0.86$ \\
\hline $\mathrm{A} / \mathrm{A}$ & $0.26(9)$ & $0.15(12)$ & $0.26(0.15-1.64) 0.50$ \\
\hline $\operatorname{HWE}\left(\chi^{2} ; p\right)$ & $3.15 ; 0.08$ & $2.88 ; 0.09$ & - \\
\hline Italy & $\mathrm{n}=18$ & $\mathrm{n}=89$ & \\
\hline G & $0.36(13)$ & $0.40(71)$ & Reference \\
\hline A & $0.64(23)$ & $0.60(107)$ & $0.71(0.53-2.70) 1.17$ \\
\hline $\mathrm{G} / \mathrm{G}$ & $0.06(1)$ & $0.16(14)$ & Reference \\
\hline $\mathrm{A} / \mathrm{G}$ & $0.61(11)$ & $0.48(43)$ & $0.79(0.20-2.45) 0.73$ \\
\hline $\mathrm{A} / \mathrm{A}$ & $0.33(6)$ & $0.36(32)$ & $0.66(0.27-129.16) 2.58$ \\
\hline $\operatorname{HWE}\left(\chi^{2} ; p\right)$ & $1.89 ; 0.17$ & $0.005 ; 0.94$ & - \\
\hline
\end{tabular}

CI: confidence interval; HWE: Hardy Weinberg equilibrium; LTF: lactoferrin encoding gene; OR: odds ratio; SNP: single nucleotide polymorphism.

infection susceptibility (Defer et al. 1995, Semba et al. 1998, Dapsanse et al. 2001) and AIDS progression (van der Strate et al. 2001). Additionally, recent works have explored the role of lactotransferrin in the oral health among HIV-1 infected subjects. Alves et al. (2014) observed higher salivary lactotransferrin levels in HIV-1 infected children during Candida sp. oral colonisation. Ferreira et al. (2014) reported no lactotransferrin level alterations in gingival crevicular fluid and saliva from HIV-1 infected subjects with chronic periodontitis.

To the best of our knowledge, no studies so far investigated the possible association between $L T F$ genetic variants and susceptibility to HIV-1 infection or with progression to AIDS and its clinical manifestations.

Two functional polymorphisms within LTF gene, named Thr29Ala and Arg47Lys, were previously associated with an increased susceptibility to periodontitis de- velopment (Velliyagounder et al. 2003, Jordan et al. 2005, Wu et al. 2009), dental caries (Azevedo et al. 2010, Fine et al. 2013), ovarian cancer (Cao et al. 2011), nasopharyngeal carcinoma (Zhou et al. 2012), dyslipidaemia (Moreno-Navarrete et al. 2008) and coronary artery stenosis (Videm et al. 2012). In our study, the Thr29Ala and Arg47Lys polymorphisms were analysed in order to investigate the possible role of these $L T F$ genetic variants on HIV-1 MTCT.

Our association analysis, performed among children born from HIV-1 positive mothers from four different populations, indicates that the LTF Thr29Ala and Arg47Lys allele, genotype and haplotype frequencies, are similar in HIV-1 infected and HIV-1 EU children and are also comparable to those reported by the HapMap project (International HapMap Consortium 2003) and 1000 Genomes project (GPC et al. 2012); the Brazilian population does not follow the same frequency distribution, 


\section{TABLE III}

LTF Thr29Ala polymorphism allele, genotype frequencies (and counts) in human immunodeficiency virus (HIV) positive $(+)$ plus negative $(-)$ children in the four different populations compared with the most similar ethnic group reported by HapMap and 1000 Genomes project

\begin{tabular}{|c|c|c|c|}
\hline $\begin{array}{l}\text { LTF SNP } \\
\text { Thr29Ala (rs1126477) }\end{array}$ & $\begin{array}{c}\text { Total } \\
(\mathrm{HIV}+\text { plus HIV-) }\end{array}$ & $\begin{array}{c}\text { HapMap/ } \\
1000 \text { Genomes }\end{array}$ & $\begin{array}{c}\text { Total vs. } \\
\text { Hapmap/ } \\
1000 \text { Genomes } \\
\text { p (CI) OR }\end{array}$ \\
\hline & $\begin{array}{l}\text { Africa } \\
(\mathrm{n}=41)\end{array}$ & $\begin{array}{l}\text { HapMap-YRI } \\
\quad(\mathrm{n}=113)\end{array}$ & \\
\hline A & $0.77(63)$ & $0.85(192)$ & Reference \\
\hline G & $0.23(19)$ & $0.15(34)$ & $0.12(0.85-3.32) 1.70$ \\
\hline $\mathrm{A} / \mathrm{A}$ & $0.61(25)$ & $0.70(79)$ & Reference \\
\hline $\mathrm{A} / \mathrm{G}$ & $0.32(13)$ & $0.30(34)$ & $0.69(0.50-2.80) 1.21$ \\
\hline \multirow[t]{2}{*}{$\mathrm{G} / \mathrm{G}$} & $0.07(3)$ & $0.00(0)$ & Not calculable \\
\hline & $\begin{array}{l}\text { India } \\
(\mathrm{n}=76)\end{array}$ & $\begin{array}{c}1000 \text { Genomes-ASN }^{b} \\
(\mathrm{n}=286)\end{array}$ & \\
\hline A & $0.42(64)$ & $0.40(229)$ & Reference \\
\hline $\mathrm{G}$ & $0.58(88)$ & $0.60(343)$ & $0.64(0.63-1.34) 0.92$ \\
\hline $\mathrm{A} / \mathrm{A}$ & $0.14(11)$ & $0.17(49)$ & Reference \\
\hline $\mathrm{A} / \mathrm{G}$ & $0.55(42)$ & $0.46(131)$ & $0.38(0.65-3.32) 1.43$ \\
\hline \multirow[t]{2}{*}{$\mathrm{G} / \mathrm{G}$} & $0.30(23)$ & $0.37(106)$ & $1.00(0.41-2.38) 0.97$ \\
\hline & $\begin{array}{c}\text { Brazil } \\
(n=113)\end{array}$ & $\begin{array}{c}1000 \text { Genomes-AMR }^{c} \\
(\mathrm{n}=199)\end{array}$ & \\
\hline A & $0.52(117)$ & $0.41(149)$ & Reference \\
\hline G & $0.48(109)$ & $0.59(213)$ & $0.01(0.46-0.92) 0.65$ \\
\hline $\mathrm{A} / \mathrm{A}$ & $0.32(36)$ & $0.19(34)$ & Reference \\
\hline $\mathrm{A} / \mathrm{G}$ & $0.40(45)$ & $0.45(81)$ & $0.03(0.28-0.99) 0.53$ \\
\hline \multirow[t]{2}{*}{$\mathrm{G} / \mathrm{G}$} & $0.28(32)$ & $0.36(66)$ & $0.02(0.23-0.90) 0.46$ \\
\hline & $\begin{array}{c}\text { Italy } \\
(\mathrm{n}=107)\end{array}$ & $\begin{array}{l}\text { HapMap-TSI }^{d} \\
\qquad(\mathrm{n}=88)\end{array}$ & \\
\hline A & $0.30(64)$ & $0.26(46)$ & Reference \\
\hline $\mathrm{G}$ & $0.70(150)$ & $0.74(130)$ & $0.43(0.52-1.32) 0.83$ \\
\hline $\mathrm{A} / \mathrm{A}$ & $0.11(12)$ & $0.06(5)$ & Reference \\
\hline $\mathrm{A} / \mathrm{G}$ & $0.37(40)$ & $0.41(36)$ & $0.27(0.12-1.60) 0.47$ \\
\hline $\mathrm{G} / \mathrm{G}$ & $0.51(55)$ & $0.53(47)$ & $0.29(0.13-1.63) 0.49$ \\
\hline
\end{tabular}

$a$ : Yoruba, Ibadan, Nigeria; $b$ : an admixture from Han-Chinese in Beijng, China, Southern Han Chinese, Japanese in Tokyo, Japan; $c$ : an admixture of Colombian from Medellin, Colombia, Mexican ancestry from Los Angeles, United States of America, Puerto Ricans, from Puerto Rico; $d$ : Toscans, Italy; CI: confidence interval; LTF: lactoferrin encoding gene; OR: odds ratio; SNP: single nucleotide polymorphism.

probably due to the ethnic heterogeneity among Brazilians, that are an admixture of African, Caucasian and native American populations (Alves-Silva et al. 2000), and considering that the AMR population that was used as a comparison is not a Brazilian one, but is an admixture of Colombian from Medellin, Mexican ancestry from Los Angeles and Puerto Ricans.

During descriptive analysis, African and Italian populations seemed to present opposite allelic frequencies. On the other hand, among the Indian and the Brazilian subjects, the frequencies of the two polymorphisms seemed to be similar.

No significant differences were found when comparing HIV-1 positive and HIV-1 negative children, sug- gesting that the two LTF polymorphisms could be not involved in HIV-1 vertical transmission. However, the data are preliminary and the comparison of the frequencies among the distinct human groups is quite complex to be performed: it is not excluded that the lack of association may be due in part to the small sample size of the populations investigated combined with a small effect of $L T F$ in HIV-1 susceptibility, a multifactorial trait. Indeed, although the total number of analysed individual was 337 , the classification in HIV-1 positive and negative and in the four subgroups based on ethnic origins led to a reduction of the power of the study. In fact, except for the haplotype analysis in the Brazilian population $($ power $=0.96)$, all other tests had a low power $(0.07$ 


\section{TABLE IV}

LTF Arg47Lys polymorphism allele, genotype frequencies (and counts) in human immunodeficiency virus (HIV) positive (+) plus negative (-) children in the four different populations compared with the most similar ethnic group reported by HapMap and 1000 Genomes project

\begin{tabular}{|c|c|c|c|}
\hline $\begin{array}{l}\text { LTF SNP } \\
\text { Arg47Lys (rs1126478) }\end{array}$ & $\begin{array}{c}\text { Total } \\
(\mathrm{HIV}+\text { plus HIV-) }\end{array}$ & $\begin{array}{c}\text { HapMap/ } \\
1000 \text { Genomes }\end{array}$ & $\begin{array}{c}\text { Total vs. } \\
\text { Hapmap/ } \\
1000 \text { Genomes } \\
\text { p (CI) OR }\end{array}$ \\
\hline & $\begin{array}{l}\text { Africa } \\
(\mathrm{n}=41)\end{array}$ & $\begin{array}{l}\text { HapMap-YRI } \\
\quad(\mathrm{n}=113)\end{array}$ & \\
\hline G & $0.97(79)$ & $0.99(223)$ & Reference \\
\hline A & $0.03(3)$ & $0.01(3)$ & $0.19(0.37-21.43) 2.81$ \\
\hline $\mathrm{G} / \mathrm{G}$ & $0.93(39)$ & $0.97(110)$ & Reference \\
\hline $\mathrm{A} / \mathrm{G}$ & $0.07(1)$ & $0.03(3)$ & $1.00(0.02-12.11) 0.94$ \\
\hline \multirow[t]{2}{*}{$\mathrm{A} / \mathrm{A}$} & $0.00(1)$ & $0.00(0)$ & Not calculable \\
\hline & $\begin{array}{c}\text { India } \\
(\mathrm{n}=76)\end{array}$ & $\begin{array}{c}1000 \text { Genomes-ASN }^{b} \\
(\mathrm{n}=286)\end{array}$ & \\
\hline G & $0.66(99)$ & $0.65(371)$ & Reference \\
\hline A & $0.34(53)$ & $0.35(201)$ & $1.00(0.66-1.46) 0.99$ \\
\hline $\mathrm{G} / \mathrm{G}$ & $0.39(29)$ & $0.43(124)$ & Reference \\
\hline $\mathrm{A} / \mathrm{G}$ & $0.55(41)$ & $0.43(123)$ & $0.22(0.81-2.54) 1.42$ \\
\hline \multirow[t]{2}{*}{$\mathrm{A} / \mathrm{A}$} & $0.06(6)$ & $0.14(39)$ & $0.51(0.21-1.78) 0.66$ \\
\hline & $\begin{array}{c}\text { Brazil } \\
(\mathrm{n}=113)\end{array}$ & $\begin{array}{c}1000 \text { Genomes-AMR }^{c} \\
(\mathrm{n}=199)\end{array}$ & \\
\hline G & $0.57(144)$ & $0.47(169)$ & Reference \\
\hline A & $0.43(82)$ & $0.53(193)$ & $0.00006(0.35-0.71) 0.50$ \\
\hline G/G & $0.40(52)$ & $0.24(44)$ & Reference \\
\hline $\mathrm{A} / \mathrm{G}$ & $0.34(40)$ & $0.45(81)$ & $0.002(0.23-0.75) 0.42$ \\
\hline \multirow[t]{2}{*}{$\mathrm{A} / \mathrm{A}$} & $0.26(21)$ & $0.31(56)$ & $0.0004(0.16-0.63) 0.32$ \\
\hline & $\begin{array}{c}\text { Italy } \\
(\mathrm{n}=107)\end{array}$ & $\begin{array}{l}\text { HapMap-TSI } \\
\quad(\mathrm{n}=88)\end{array}$ & \\
\hline $\mathrm{G}$ & $0.36(84)$ & $0.33(59)$ & Reference \\
\hline A & $0.64(130)$ & $0.67(117)$ & $0.25(0.50-1.21) 0.78$ \\
\hline $\mathrm{G} / \mathrm{G}$ & $0.06(15)$ & $0.10(9)$ & Reference \\
\hline $\mathrm{A} / \mathrm{G}$ & $0.61(54)$ & $0.47(41)$ & $0.65(0.28-2.16) 0.79$ \\
\hline $\mathrm{A} / \mathrm{A}$ & $0.33(38)$ & $0.43(38)$ & $0.35(0.20-1.68) 0.60$ \\
\hline
\end{tabular}

$a$ : Yoruba, Ibadan, Nigeria; $b$ : an admixture from Han-Chinese in Beijng, China, Southern Han Chinese, Japanese in Tokyo, Japan; $c$ : an admixture of Colombian from Medellin, Colombia, Mexican ancestry from Los Angeles, United States of America, Puerto Ricans, from Puerto Rico; $d$ : Toscans, Italy; CI: confidence interval; LTF: lactoferrin encoding gene; OR: odds ratio; SNP: single nucleotide polymorphism.

for African population; 0.51 for Indian populations and 0.32 for Italian population). The unavailability of other samples did not allow us to increase the sample size; this was a limitation of our study that could affect the evaluation of the potential role of $L T F$ genetic variants in the context of susceptibility to HIV-1 infection.

It is also important to consider the difficulties in comparing LTF SNPs frequencies within the groups, also assuming that the populations studied are sets of individuals from different ethnic origins. However, even if the number of individuals is limited, we tried to replicate the association findings in different ethnic groups, being aware that any replica and comparison within the four analysed groups is quite difficult due to the low frequency of $L T F$ SNPs.
Previous findings suggested that lactotransferrin could play a role in HIV-1 vertical transmission, but no studies have been conducted on the ability of the two $L T F$ variants to prevent HIV-1 entry to the cells or to interfere with the viral processes. Considering our negative results we could speculate that, although the two polymorphisms are not synonymous and result in two amino acidic substitutions, these variations may not modify the antiviral activity of the mature protein; the PolyPhen-2 (Adzhubei et al. 2010) software predicted the two SNPs as benign and thus not able to radically affect the protein. Another hypothesis is that if even the two polymorphisms could influence the antiviral role of the protein, perhaps an increment in gene expression, due to 
TABLE V

LTF haplotype frequencies (and counts) in human immunodeficiency virus (HIV) positive (+) and negative (-) children in the four different populations analysed

\begin{tabular}{|c|c|c|c|}
\hline $\begin{array}{l}\text { LTF haplotypes } \\
\text { (Thr29Ala-Arg47Lys) }\end{array}$ & HIV- & HIV+ & $\begin{array}{l}\text { HIV- vs. HIV+ } \\
\text { (p) }\end{array}$ \\
\hline Africa & $\mathrm{n}=30$ & $\mathrm{n}=52$ & \\
\hline $\mathrm{AG}$ & $0.77(23)$ & $0.77(40)$ & 1.00 \\
\hline GG & $0.20(6)$ & $0.19(10)$ & \\
\hline GA & $0.03(1)$ & $0.04(2)$ & \\
\hline AA & $0.00(0)$ & $0.00(0)$ & \\
\hline LD (p; D’; r²) & $0.07 ; 0.99 ; 0.11$ & $0.01 ; 0.99 ; 0.13$ & - \\
\hline India & $\mathrm{n}=62$ & $\mathrm{n}=90$ & \\
\hline $\mathrm{AG}$ & $0.47(29)$ & $0.39(35)$ & 0.56 \\
\hline GG & $0.19(12)$ & $0.25(23)$ & \\
\hline GA & $0.34(21)$ & $0.36(32)$ & \\
\hline AA & $0.00(0)$ & $0.00(0)$ & \\
\hline LD (p; D'; r²) & $<0.01 ; 0.99 ; 0.45$ & $<0.01 ; 0.99 ; 0.35$ & - \\
\hline Brazil & $\mathrm{n}=70$ & $\mathrm{n}=156$ & \\
\hline $\mathrm{AG}$ & $0.46(32)$ & $0.51(79)$ & 0.19 \\
\hline GA & $0.37(26)$ & $0.32(50)$ & \\
\hline GG & $0.11(8)$ & $0.16(25)$ & \\
\hline $\mathrm{AA}$ & $0.06(4)$ & $0.01(2)$ & \\
\hline LD (p; D'; r²) & $<0.01 ; 0.72 ; 0.41$ & $<0.01 ; 0.91 ; 0.45$ & - \\
\hline Italy & $\mathrm{n}=36$ & $\mathrm{n}=178$ & \\
\hline GA & $0.64(23)$ & $0.60(106)$ & 0.85 \\
\hline $\mathrm{AG}$ & $0.25(9)$ & $0.30(54)$ & \\
\hline GG & $0.11(4)$ & $0.10(17)$ & \\
\hline AA & $0.00(0)$ & $0.01(1)$ & \\
\hline LD (p; D'; r²) & $<0.01 ; 0.99 ; 0.59$ & $<0.01 ; 0.97 ; 0.63$ & - \\
\hline
\end{tabular}

LD: linkage disequilibrium; LTF: lactoferrin encoding gene.

external factors other than genetic variations, may compensate the alterations within the molecule. A study conducted by Moreno-Navarrete et al. (2008) showed that the two LTF polymorphisms did not correlate with the plasma protein level in a Spanish population.

Unfortunately, in this study, being a retrospective one performed on historical groups of HIV-1 patients infected trough vertical transmission, biological samples other than DNA were not available to perform functional studies and investigating the effective influence of $L T F$ genetic variants on protein production or on protein functionality. Other limitations of the study are the lack of information about the mother's genotypes and regarding breastfeeding occurrence.

Our results suggest that $L T F$ genetic polymorphisms Thr29Ala and Arg47Lys are not associated with susceptibility to HIV-1 MTCT, but our data are preliminary, obtained on low number of individual, also lacking of functional characterisation of the analysed SNPs. Therefore, further large-scale studies and functional analysis are necessary to clarify the potential role of LTF gene polymorphisms in HIV-1 infection susceptibility.

\section{REFERENCES}

Adzhubei IA, Schmidt S, Peshkin L, Ramensky VE, Gerasimova A, Bork P, Kondrashov AS, Sunyaev SR 2010. A method and server for predicting damaging missense mutations. Nat Methods 7: 248-249.

Alves TP, Simoes AC, Soares RM, Moreno DS, Portela MB, Castro GF 2014. Salivary lactoferrin in HIV-infected children: correlation with Candida albicans carriage, oral manifestations, HIV infection and its antifungal activity. Arch Oral Biol 59: 775-782.

Alves-Silva J, Santos MS, Guimarães PE, Ferreira AC, Bandelt HJ, Pena SD, Prado VF 2000. The ancestry of Brazilian mtDNA lineages. Am J Hum Genet 67: 444-461.

Azevedo LF, Pecharki GD, Brancher JA, Cordeiro Jr CA, Medeiros KG, Antunes AA, Arruda ES, Werneck RI, de Azevedo LR, Mazur RF, Moysés SJ, Moysés ST, Faucz FR, Trevilatto PC 2010. Analysis of the association between lactotransferrin $(L T F)$ gene polymorphism and dental caries. J Appl Oral Sci 18: 166-170.

Berkhout B, van Wamel JL, Beljaars L, Meijer DK, Visser S, Floris R 2002. Characterization of the anti-HIV effects of native lactoferrin and other milk proteins and protein-derived peptides. Antiviral Res 55: 341-355.

Cao L, Zhou Y, Li X, Yi H 2011. The relationship of haplotype in lactotransferrin and its expression levels in Chinese Han ovarian cancer. Acta Biochim Biophys Sin (Shanghai) 43: 884-890. 
Clayton D 2013. snpStats: SnpMatrix and XSnpMatrix classes and methods. R package version 1.14.0.

Dapsanse V, Defer MC, Follézou JY, Dugas B, Postaire E, Picard O, Damais C 2001. Differential pattern in circulating nitrogen derivatives, lactoferrin and anti-lactoferrin antibodies in HIV type 1 and HIV type 2 infections. AIDS Res Hum Retroviruses 17: 1041-1045.

Datta P, Embree JE, Kreiss JK, Ndinya-Achola JO, Braddick M, Temmerman M, Nagelkerke NJD, Maitha G, Holmes KK, Piot P, Pamba HO, Plummer FA 1994. Mother-to-child transmission of human immunodeficiency virus type 1: report of the Nairobi study. J Infect Dis 170: 1134-1140.

Defer MC, Dugas B, Picard O, Damias C 1995. Impairment of circulating lactoferrin in HIV-1 infection. Cell Mol Biol 41: 417-421.

Excoffier L, Lischer HE 2010. Arlequin suite ver 3.5: a new series of programs to perform population genetics analyses under Linux and Windows. Mol Ecol Resour 10: 564-567.

Faul F, Erdfelder E, Lang AG, Buchner A 2007. G*Power 3: a flexible statistical power analysis program for the social, behavioral and biomedical sciences. Behav Res Methods 39: 175-191.

Ferreira SM, Gonçalves LS, Torres SR, Nogueira SA, Meiller TF 2014. Lactoferrin levels in gingival crevicular fluid and saliva of HIV-infected patients with chronic periodontitis. J Investig Clin Dent 6: 16-24.

Fine DH, Toruner GA, Velliyagounder K, Sampathkumar V, Godboley D, Furgang D 2013. A lactotransferrin single nucleotide polymorphism demonstrates biological activity that can reduce susceptibility to caries. Infect Immun 81: 1596-1605.

GPC - Genomes Project Consortium, Abecasis GR, Auton A, Brooks LD, DePristo MA, Durbin RM, Handsaker RE, Kang HM, Marth GT, McVean GA 2012. An integrated map of genetic variation from 1,092 human genomes. Nature 491: 56-65.

Groot F, Geijtenbeek TB, Sanders RW, Baldwin CE, SánchezHernández M, Floris R, van Kooyk Y, de Jong EC, Berkhout B 2005. Lactoferrin prevents dendritic cell-mediated human immunodeficiency virus type 1 transmission by blocking the DCSIGN-gp120 interaction. J Virol 79: 3009-3015.

International HapMap Consortium 2003. The International HapMap Project. Nature 426: 789-796.

Jordan WJ, Eskdale J, Lennon GP, Pestoff R, Wu L, Fine DH, Gallagher G 2005. A non-conservative, coding single-nucleotide polymorphism in the N-terminal region of lactoferrin is associated with aggressive periodontitis in an African-American, but not a Caucasian population. Genes Immun 6: 632-635.

Kazmi SH, Naglik JR, Sweet SP, Evans RW, O’Shea S, Banatvala JE, Challacombe SJ 2006. Comparison of human immunodeficiency virus type 1-specific inhibitory activities in saliva and other human mucosal fluids. Clin Vaccine Immunol 10: 1111-1118.
Legardy-Williams JK, Jamieson DJ, Read JS 2010. Prevention of mother-to-child transmission of EU1: the role of cesarean delivery. Clin Perinatol 37: 777-785.

Moreno-Navarrete JM, Ortega FJ, Bassols J, Castro A, Ricart W, Fernández-Real JM 2008. Association of circulating lactoferrin concentration and 2 nonsynonymous LTF gene polymorphisms with dyslipidemia in men depends on glucose-tolerance status. Clin Chem 54: 301-309.

Ng TB, Lam TL, Au TK, Ye XY, Wan CC 2001. Inhibition of human immunodeficiency virus type 1 reverse transcriptase, protease and integrase by bovine milk proteins. Life Sci 69: 2217-2223.

R Development Core Team 2014. R: a language and environment for statistical computing. Available from: R-project.org/.

Semba RD, Miotti PG, Lan Y, Chiphangwi JD, Hoover DR, Dallabetta GA, Yang LP, Saah AJ 1998. Maternal serum lactoferrin and vertical transmission of HIV. AIDS 12: 331-332.

Shanbacher FL, Goodman RE, Talhouk RS 1993. Bovine mammary lactoferrin: implications from messenger ribonucleic acid (mRNA) sequence and regulation contrary to other milk proteins. J Dairy Sci 76: 3812-3831.

Sole X, Guino E, Valls J, Iniesta R, Moreno V 2006. SNPStats: a web tool for the analysis of association studies. Bioinformatics 22: 1928-1929.

Teng CT, Gladwell W 2006. Single nucleotide polymorphisms (SNPs) in human lactoferrin gene. Biochem Cell Biol 84: 381-384.

van der Strate BW, Belijaars L, Molema G, Harmsen MC, Meijer DK 2001. Antiviral activities of lactoferrin. Antiviral Res 52: 225-239.

Velliyagounder K, Kaplan JB, Furgang D, Legarda D, Diamond G, Parkin RE, Fine DH 2003. One of two human lactoferrin variants exhibits increased antibacterial and transcriptional activation activities and is associated with localized juvenile periodontitis. Infect Immun 71: 6141-6147.

Videm V, Dahl H, Wålberg LE, Wiseth R 2012. Functional polymorphisms in the LTF gene and risk of coronary artery stenosis. Hum Immunol 73: 554-559.

Wong JH, Liu Z, Law KW, Liu F, Xia L, Wan DC, Ng TB 2014. A study of effects of peptide fragments of bovine and human lactoferrins on activities of three key HIV-1 enzymes. Peptides 62: 183-188.

WHO - World Health Organization 2013. Global summer of HIV epidemic. Available from: who.int/hiv/data/en/.

Wu YM, Juo SH, Ho YP, Ho KY, Yang YH, Tsai CC 2009. Association between lactoferrin gene polymorphisms and aggressive periodontitis among Taiwanese patients. J Periodontal Res 44: 418-424.

Zhou Y, Wang W, Zheng D, Peng S, Xiong W, Ma J, Zeng Z, Wu M, Zhou M, Xiang J, Xiang B, Li X, Li X, Li G 2012. Risk of nasopharyngeal carcinoma associated with polymorphic lactotransferrin haplotypes. Med Oncol 29: 1456-1462. 